\title{
RCD Holdings Ltd v LT Game International (Australia) Ltd: Foreign jurisdiction clauses and COVID-19
}

By Jie (Jeanne) Huang, Associate Professor, University of Sydney Law School Australia

In 2013, the plaintiffs, ePayment Solutions Pty Ltd (EPS) and RCD Holdings Ltd (RCD) concluded a written contract with the defendant, LT Game International (Australia) Ltd (LT) about the development and installation of a computer betting game. LT is a company incorporated in the Virgin Islands and registered in Australia as a foreign company. The contract was signed in Australia. Its Clause 10 provides.

\section{“10. Governing Law}

Any dispute or issue arising hereunder, including any alleged breach by any party, shall be heard, determined and resolved by an action commenced in Macau. The English language will be used in all documents."

When a dispute arose, the plaintiffs commenced the proceedings at the Supreme Court of Queensland in Australia ([2020] QSC 318). The defendant entered a conditional appearance and applied to strike out the claim, or alternatively, to have it stayed as being commenced in this court contrary to the contract. This case shed useful light on how an Australian court may address the impacts of COVID-19 on foreign jurisdiction clauses.

The parties did not dispute that Clause 10 was an exclusive jurisdiction clause choosing courts in Macau China. However, an exclusive foreign jurisdiction clause does not exclude Australian courts' jurisdiction. The plaintiffs alleged that the Supreme Court of Queensland should not enforce the exclusive jurisdiction clause due to the COVID?19 pandemic for two reasons. 
First, the pandemic currently prevents the plaintiffs from commencing proceedings in Macau. The court rejected this argument because no evidence suggested that representatives of the plaintiffs had to be present in Macau for lawyers retained by them to commence proceedings.

Second, plaintiffs also alleged that their witnesses could not travel from Australia to Macau because of the pandemic. The court also rejected this argument because of insufficient evidence. According to the court, the plaintiffs did not provide any evidence of the impact of COVID?19 in Macau, for example, what restrictions were being experienced now, what restrictions were likely to be experienced in the future and how long those restrictions may persist. There was also no evidence showing when a trial of proceedings commenced now in Macau might be heard. Although Australian witnesses might be called in the Macau proceedings, the plaintiffs did not identify any specific persons who would be called were residents in Australia. It was also unclear whether overseas witnesses might be called if the proceedings were conducted in Australia as Australia also imposed strict travel restrictions.

Finally, the court ruled for the defendant and dismissed the plaintiffs' claim. Nevertheless, the court indicated that the plaintiffs could recommence the proceedings in Queensland if the circumstances of the COVID-19 pandemic changed materially in Macao in the future.

\section{Comments:}

It is well established that an exclusive foreign jurisdiction clause does not operate to exclude Australian courts' jurisdiction; however, the courts will hold the parties to their bargain and grant a stay of proceedings, unless the party who seeks that the proceedings be heard in Australia can show that there are strong reasons against litigating in the foreign jurisdiction.[1] In exercising its discretion, the court should take into account all the circumstances of the particular case. However, doubts have been cast as to whether courts should consider financial or forensic inconvenience attaching to the nominated foreign jurisdiction, at least when these factors should have been known to the parties at the time the exclusive jurisdiction clause was agreed by them.[2]

In $R C D$, the court correctly held that Clause 10 should be interpreted as manifesting an intention that disputes would be determined in Macau by applying 
the law of Macau. Although the application of Macau law might bring financial benefits to the defendant because it is more difficult to prove liability for damages under the Macau law than the law in Australia. However, this is insufficient to convince the court to exercise jurisdiction because the potential financial benefits for the defendant are what the parties have bargained for.

Regarding the location of witnesses, the court is also correct that parties should expect that breaches may occur in Australia as the contract would be partially performed there, and consequently, witnesses in Australia may need to be called for proceedings in Macao. Therefore, the location and travel of witnesses are not a strong reason for Australian courts to exercise jurisdiction.

The outbreak of the COVID-19 pandemic is a factor that parties could not reasonably expect when they concluded their foreign jurisdiction clause. If a plaintiff wants to convince an Australian court to exercise jurisdiction in spite of an exclusive foreign jurisdiction clause, this plaintiff must provide solid evidence of the impacts of the COVID-19 pandemic on foreign proceedings. If the plaintiff can show that the pandemic developed so as to effectively prevent, or unduly frustrate the plaintiff in litigating in the foreign jurisdiction, then that might be a discretionary consideration, with any other relevant considerations, in favor of allowing the plaintiffs to litigate in Australia.

[1] High Court of Australia decisions such as Akai Pty Ltd v People's Insurance Co Ltd (1996) 188 CLR 418 at 445, Oceanic Sunline Special Shipping Company Inc v Fay (1988) 165 CLR 197 at 259, Huddart Parker Ltd v The Ship Mill Hill (1950) 81 CLR 502 at 508-509.

Decisions of intermediate courts of appeal such as Global Partners Fund Ltd $v$ Babcock \& Brown Ltd (in liq) \& Ors (2010) 79 ACSR 383 at 402-403, [88]-[89], Australian Health \& Nutrition Association Ltd \& Anor v Hive Marketing Group Pty Ltd \& Anor (2019) 99 NSWLR 419 at 438, [78], Venter v Ilona MY Ltd [2012] NSWSC 1029.

[2] Incitec Ltd v Alkimos Shipping Corp (2004) 138 FCR 496 at 506 and Australian Health \& Nutrition Association Ltd \& Anor v Hive Marketing Group Pty Ltd \& Anor (2019) 99 NSWLR 419. 